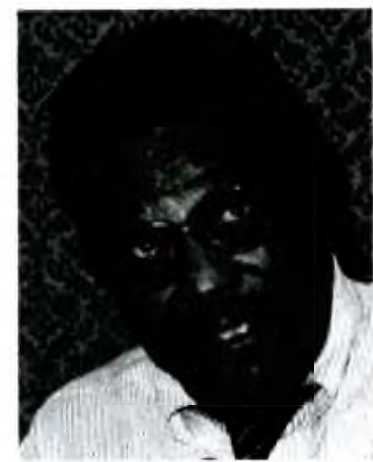

Samuel Proctor

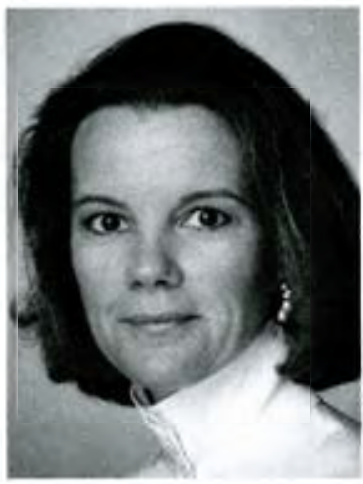

Mary Anne Dolan

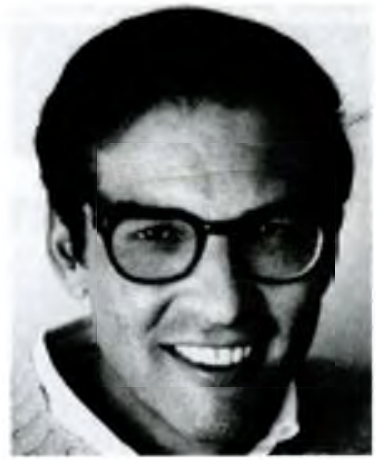

Robert A. Caro

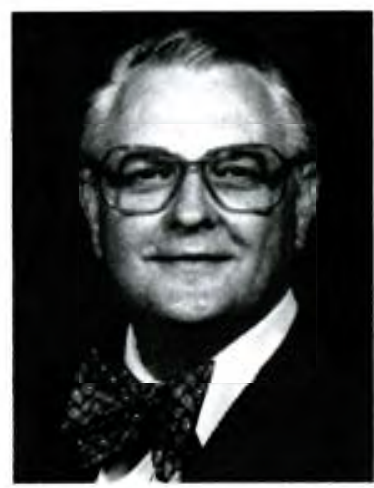

Edward G. Holley

\title{
Theme Speakers
}

The theme speakers at the ACRL National Conference are generously sponsored by EBSCO Subscription Services.

Samuel D. Proctor is a clergyman, educator and author. He served as the associate general secretary of the National Council of Churches during the 1960 s and became the senior pastor of the Abyssinian Baptist Church in New York City in 1972. He is a former president of Virginia Union University (1955-1960) and North Carolina A \& T State University (1960-1964) as well as a former associate director of the Peace Corps. From 1964 to 1984 he was Martin Luther King Professor in the Graduate School of Education at Rutgers. Since his retirement in 1984 he has been professor emeritus there.

Proctor's books include The Young Negro in America, 1960-1980 (Association Press, 1966) and Sermons from the Black Pulpit (Judson, 1984). He has received numerous awards and honorary degrees.

Robert A. Caro is a Pulitzer Prize-winning author. As a muckraking reporter for Newsday, the Long Island (New York) daily newspaper, in the 1960 s, Caro became interested in how power works. Out of that interest came two panoramic sagas, each seven years in the writing and both best sellers. The first was The Power Broker: Robert Moses and the Fall of New York (Knopf, 1974), a biography of the unelected "master builder" who made himself the most powerful figure in the City and State of New York in our time. The work won the Pulitzer Prize for biography and the Society of American Historians' Francis Parkman Prize for the book "which best represents the union of the historian and the artist."

Caro's second best seller was The Path to Power 
(Knopf, 1982), the first volume in a projected trilogy about the thirty-sixth president of the United States, The Years of Lyndon Johnson.

Mary Anne Dolan is a syndicated columnist and television commentator based in Los Angeles. In 1981 Dolan became the first woman in America to rise through the ranks to the editorship of a major metropolitan newspaper, The Los Angeles Herald Examiner. Dolan came to the editorship of the Herald after nearly 10 years in executive newspaper jobs and after many more years working with colleagues to promote a greater role for women in journalism. Dolan wrote an article, "When Feminism Failed," for the June 26, 1988, issue of The New York Times Magazine. In the article, she talks about a problem she encountered at the Herald: "many of these women (executives at the Herald) were content to go along with a humanizing philosophy in the workplace as a diversion only. Their essential creed was an ancient male one: power first." Dolan will address this issue at the conference. A panel of reactors will consider the implications for librarianship.

Edward G. Holley, professor, School of Information and Library Science, University of North Carolina at Chapel Hill, will be the featured speaker at the April 6th luncheon. Holley will speak on "Building a Firm Foundation: ACRL Leadership, 1939-1989." The luncheon is in honor of all ACRL past presidents and executive secretaries and directors.

Holley, who received his doctorate from the University of Illinois, served as professor and dean at Chapel Hill, from 1972 to 1985 . A past president of ALA, Holley has received the prestigious Melvil Dewey Medal and the Joseph W. Lippincott award for notable achievement in librarianship. In 1988 Holley was selected as the Academic or Research Librarian of the Year by ACRL.

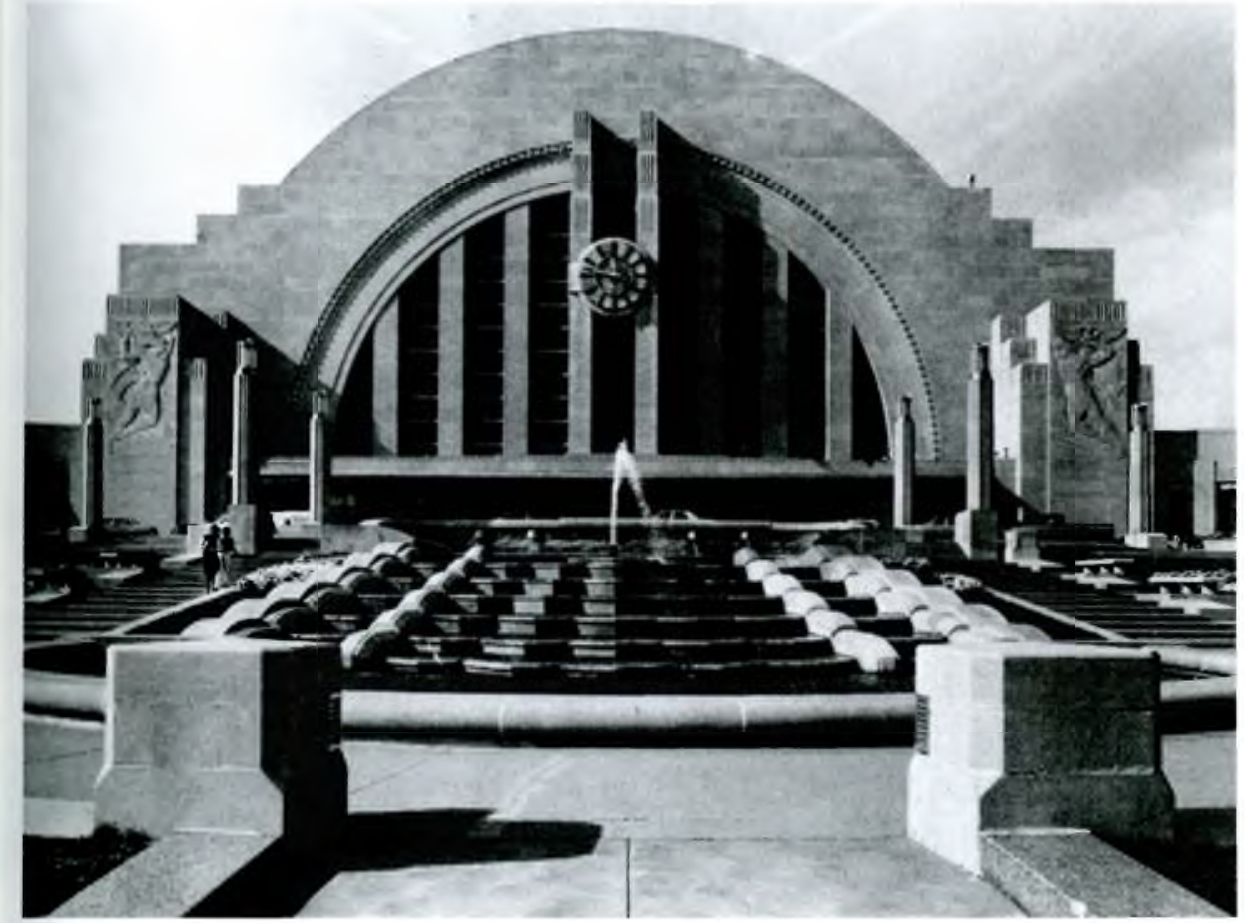

Cincinnati's Union Terminal, an art deco landmark facing $1-75$ has been transformed into a luxury theme shopping and dining mall. 
in.fo.trac /'in-fö-trak/ $n$ (1985): an automated library reference system utilizing computer access to videodisc stored databases: developed hy Information Access Company
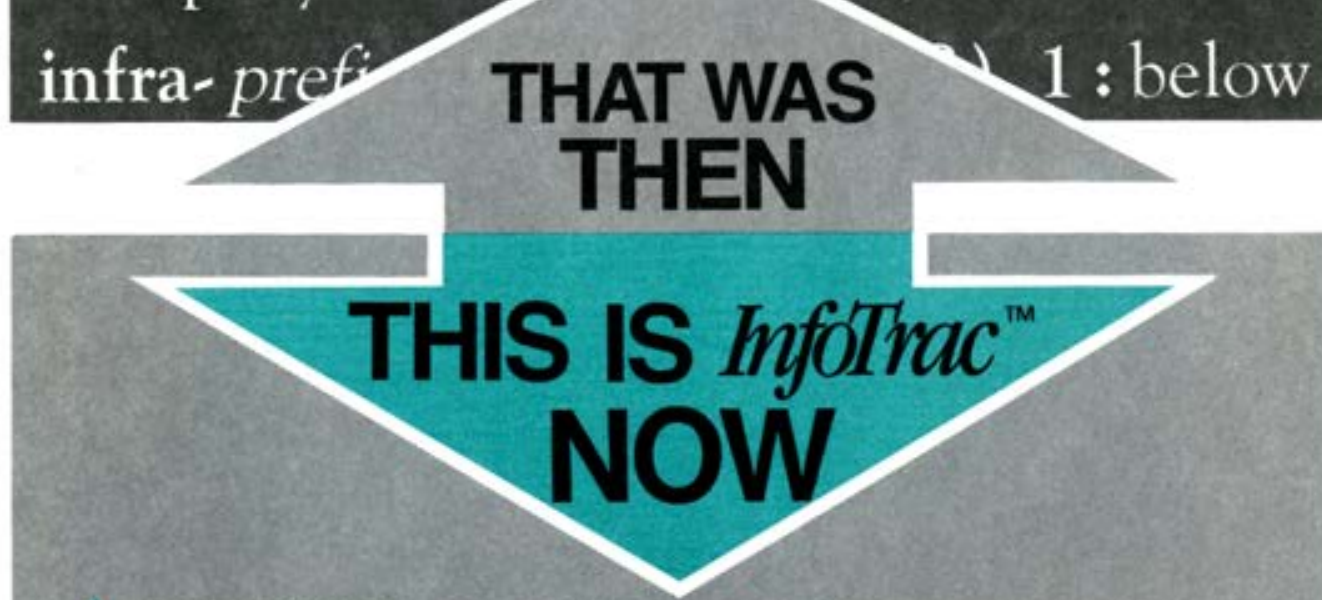

9 CD-ROM databases each designed to serve different research needs including: MAGAZINE INDEX, GENERAL PERIODICALS INDEX (public \& academic library versions), LEGALTRAC, ACADEMIC INDEX, GOVERNMENT PUBLICATIONS INDEX and our newest additions - NATIONAL NEWSPAPER INDEX, HEALTH INDEX, TOM (for secondary schools)

Search multiple InfoTrac databases from a single station select databases from a menu without switching discs or re-booting software

Use the InfoTrac Reference Center to access CD databases from other leading vendors no need to invest in separate stations for each CD-ROM system

New economical site license program

place stations anywhere in your library system and provide multiple access

Visit IAC's Booth \#425-427 at ACRL National Conference and see our full range of automated reference systems.

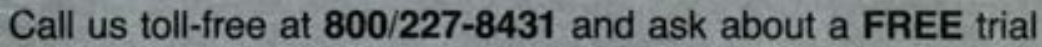
INFORMATION ACCESS COMPANY - 362 Lakeside Drive, Foster City, CA 94404 - 800/227-8431 